\title{
The thermal effect of deformation during the ECAP processing of the $\mathrm{Cu}-0.6 \mathrm{Cr}$ alloy
}

\author{
D. A. Aksenov ${ }^{\dagger, 1,2}$, R. N. Asfandiyarov ${ }^{1,2}$, G. I. Raab ${ }^{2}$, M.P. Baryshnikov ${ }^{3}$ \\ †AksyonovDA@mail.ru \\ ${ }^{1}$ Institute of Molecule and Crystal Physics, Ufa Federal Research Center RAS, Ufa, 450075, Russia \\ ${ }^{2}$ Institute of Physics of Advanced Materials, Ufa State Aviation Technical University, Ufa, 450008, Russia \\ ${ }^{3}$ Nosov Magnitogorsk State Technical University, Magnitogorsk, 455000, Russia
}

\begin{abstract}
The work is aimed at solving the problem of determining the magnitude of the thermal effect arising in an alloy of the $\mathrm{Cu}-\mathrm{Cr}$ system in the process of deformation by the ECAP method. For this, an approach was used based on the analysis of temperature and physical and mechanical characteristics of a unit volume of metal subjected to upsetting carried out on the Gleeble 3500 physical modeling complex. Upsetting was carried out at the degree of accumulated strain of $e=1.1$ at different rates of deformation $(3,30,300 \mathrm{~mm} / \mathrm{s})$ and initial temperatures $\left(20,400\right.$ and $\left.800^{\circ} \mathrm{C}\right)$. Based on the results obtained, a database was created for modeling in the Deform-3D system. The analysis of the heat capacity value is carried out and the contribution of the structural component to the used heat capacity coefficient in the Deform-3D system is estimated. Further, the ECAP process was modeled and the analysis of thermal fields and stress-strain state was carried out. It is shown that at a deformation rate of $30 \mathrm{~mm} / \mathrm{s}$, the heating reaches $99^{\circ} \mathrm{C}$ at room temperature and $63^{\circ} \mathrm{C}$ and at $400^{\circ} \mathrm{C}$. The difference between the heating temperatures, with and without taking into account the heat transfer between the sample and the tooling, does not exceed $8 \%$.
\end{abstract}

Keywords: deformation heating, ECAP, Cu-Cr alloys, Gleeble 3500, energy dissipation.

УДК: 621.7

\section{Тепловой эффект деформации при РКУП сплава $\mathrm{Cu}-0.6 \mathrm{Cr}$}

\author{
Аксенов Д. А. ${ }^{\dagger, 1,2}$, Асфандияров Р. Н., ${ }^{1,2}$, Рааб Г. И., ${ }^{2}$ Барышников М. П. ${ }^{3}$ \\ ${ }^{1}$ Институт физики молекул и кристаллов УФИЦ РАН, Уфа, 450075, Россия \\ ${ }^{2}$ Институт физики перспективных материалов при УГАТУ, Уфа, 450008, Россия \\ ${ }^{3}$ Магнитогорский государственный технический университет им. Г. И. Носова, Магнитогорск, 455000, Россия
}

\begin{abstract}
Работа посвящена решению задачи по определению величины теплового эффекта, возникающего в процессе деформации методом РКУП в сплаве системы $\mathrm{Cu}-\mathrm{Cr}$. Для этого использован подход, основанный на анализе температуры и физико-механических характеристик единичного объема металла подверженного осадке, проведенной на комплексе физического моделирования Gleeble 3500. Осадка проводилась на степень накопленной деформации $e=1.1$ при разных скоростях деформирования $\left(3,30,300\right.$ мм/с) и исходных температурах $\left(20,400\right.$ и $\left.800^{\circ} \mathrm{C}\right)$. По полученным результатам, была создана база данных для моделирования в системе Deform-3D. Проведен анализ величины теплоемкости и оценен вклад структурной составляющей в используемом коэффициенте теплоемкости в системе Deform-3D. Далее проведено моделирование процесса РКУП и проведен анализ тепловых полей и напряженно-деформированного состояния. Показано, что при скорости деформирования 30 мм/с при комнатной температуре разогрев достигает $99^{\circ} \mathrm{C}$, а при $400^{\circ} \mathrm{C}-63^{\circ} \mathrm{C}$. При этом разница между температурами разогрева с учетом теплопередачи между образцом и оснасткой и без нее не превышает $8 \%$.
\end{abstract}

Ключевые слова: деформационный разогрев, РКУП, низколегированный сплав $\mathrm{Cu}-\mathrm{Cr}$, Gleeble 3500 , диссипация энергии. 


\section{Introduction}

It is known that in the process of severe plastic deformation not only an efficient refinement of the grain structure takes place in metals $[1,2]$, but also phase transformation processes not typical of the majority of cold deformation methods are activated. In particular, strain-induced dissolution and precipitation of second-phase particles occur [3-7]. A special role in the formation of precipitates of second phases in the form of particles and segregations in dispersion-hardened copper alloys is played by the diffusion activity of impurity atoms in supersaturated metastable solutions, which is directly dependent on the actual vacancy mechanism of diffusion and thermal processing conditions [8], with the temperature most significantly affecting the value of the diffusion coefficient, and large deformation contributes to the spontaneous generation of vacancies. At large deformations, these factors can have a decisive effect on the acceleration of diffusion processes. In addition, in modern high-speed plastic processing processes, especially with large one-time deformations of metals in a fine-grained structural state, the thermal effect of deformation becomes an important factor. As a result of this, the temperature of the original workpiece can increase by several hundred degrees [9]. In its turn, processing temperature depends on the thermal effect of deformation which becomes stronger in the case of large one-time deformations and increasing processing rates [10]. For instance, there are data from the studies of deformation heating in the processes of compression [11], tension [12], equal-channel angular pressing (ECAP) and its modifications [11-15], as well as high-pressure torsion (HPT) [16]. In the reported studies, the authors employed both the direct evaluations of the thermal field using thermocouples and non-contact temperature testers, and the virtual, numerical methods of evaluation. The evaluation of the thermal effect using the above-mentioned procedures has a number of drawbacks related to the inertness of the thermocouples, the difficulty of conducting direct measurements in a closed die-set, the imperfection of the procedures used for virtual evaluation.

Analysis of changes in the thermal fields of a billet subjected to high-speed deformation processing with large one-time deformations and intense heat release is an urgent task in the creation of high-performance and technological processes for the fabrication of products from low-alloyed dispersion-hardening copper alloys. Therefore, the purpose of the present study was to develop an approach to create a database for finite element computer modeling, taking into account the thermal effects from the transformation of the structure during deformation processing. This approach allows one to search for the most reliable variable values of mathematical models used in virtual estimates of the thermal effect based on direct contact measurements of the surface temperatures of samples in free upsetting, in which direct access to the deformation zone is realized. This approach can provide mathematical modeling to estimate the temperature field of the deformation zone with greater reliability, including in a closed tooling as in ECAP. In this regard, the following tasks were set:
1. Obtaining the data for the temperature fields in the $\mathrm{Cu}-0.6 \mathrm{Cr}$ alloy samples at different upsetting rates and preliminary heating temperatures when the strain site volume and the accumulated strain level realized in the process of ECAP are provided.

2. Adjusting the variable values of the mathematical models used for the evaluation of the thermal effects during mathematical modeling, and performing the modeling of the ECAP process with the consideration of these adjustments.

\section{Material and Methods}

As the material for the study, we used the low-alloyed copper alloy $\mathrm{Cu}-0.6 \mathrm{Cr}$. The initial state of the alloy was obtained by a high-temperature treatment which consisted in holding for 1 hour at $1000^{\circ} \mathrm{C}$ followed by water quenching. The samples of the alloy with a diameter of $10 \mathrm{~mm}$ and a height of $14 \mathrm{~mm}$ were subjected to upsetting using a Gleeble-3500 physical modeling facility at deformation rates of 3,30 and $300 \mathrm{~mm} / \mathrm{s}$. The initial temperatures of upsetting were 20, 400 and $800^{\circ} \mathrm{C}$. The anvils along with the samples were subjected to preliminary heating, were held for $10 \mathrm{~s}$ and then the heating was turned off during the deformation. The temperature was controlled by means of a K-type thermocouple attached to the sample surface by resistance welding. In the process of upsetting, the strain value amounted $e=1.1$, which corresponds to the strain after one ECAP processing cycle.

The upsetting was performed with a view to adjust and verify the database and the computer simulation data. On the basis of the obtained data, a database was designed and adjusted, and the modeling of the ECAP process was performed.

Within the framework of this simulation, the following boundary conditions were determined:

- the material of the workpiece in the initial state is plastic, isotropic and there are no initial stresses and deformations in it;

- for the workpiece, a finite element mesh was generated, consisting of 20000 tetrahedrons. The minimum element size was $0.6 \mathrm{~mm}$, the maximum size was $1.2 \mathrm{~mm}$. The option to compensate the volume of the stock model has been activated;

- the tool is absolutely rigid and the tool geometry is taken into account automatically;

- simulation was performed taking into account the increase in metal temperature from the thermal effect of plastic deformation (deformation heating). The heat transfer coefficient of the tool with the workpiece was taken to be $11000 \mathrm{Wm}^{-2} \mathrm{~K}^{-1}$;

- thermal conductivity $391 \mathrm{Wm}^{-1} \mathrm{~K}^{-1}$;

- heat capacity for $\mathrm{Cu}-0.6 \mathrm{Cr}$ : range $5-7 \mathrm{Jg}^{-1} \mathrm{~K}^{-1}$ depending on temperature and rate of deformation;

- emissivity 0.3;

- Poisson's ratio 0.33;

- Young's modulus $1.15 \cdot 10^{5} \mathrm{MPa}$;

- since we simulated a volumetric deformation pattern with high contact stresses, the Siebel friction factor was used, based on experimental and literary data; the Siebel friction factor for the steel-bronze pair was taken as $0.15-0.2$; the impermeability condition was set on the contact surfaces of the rig; 
- the number of modeling steps is $120-150$;

- the finite element model describes the motion of a continuous medium based on the Lagrange approach.

\section{Results and discussion}

As a result of the analysis of the upsetting process, we have obtained the dependencies of the deformation heating and stress state for the $\mathrm{Cu}-0.6 \mathrm{Cr}$ alloy. It can be seen in Fig. $1 \mathrm{a}, \mathrm{b}$ that an increase in the initial temperature of deformation leads to a decrease in the value of heating of the alloy during the deformation. The maximum heating of the material by $79^{\circ} \mathrm{C}$ occurs at room temperature and a deformation rate of $300 \mathrm{~mm} / \mathrm{s}$. The largest difference in the heating values is observed between the deformation rates of 3 and $30 \mathrm{~mm} / \mathrm{s}$ at $20^{\circ} \mathrm{C}$. At an initial deformation temperature of $400^{\circ} \mathrm{C}$, the rates of 30 and $300 \mathrm{~mm} / \mathrm{s}$ provide heating by 31 and $36^{\circ} \mathrm{C}$, respectively, which brings the deformation temperature closer to the effective aging temperature of the $\mathrm{Cu}-0.6 \mathrm{Cr}$ alloy after ECAP processing. The decrease in the temperature of the sample at a deformation rate of $3 \mathrm{~mm} / \mathrm{s}$ and initial deformation temperatures of 400 and $800^{\circ} \mathrm{C}$ is related to the larger duration of the deformation process, as compared to the processes occurring at 30 and $300 \mathrm{~mm} / \mathrm{s}$.

The greatest strengthening at a temperature of $20^{\circ} \mathrm{C}$ is observed at a deformation rate of $300 \mathrm{~mm} / \mathrm{s}(690 \pm 20 \mathrm{MPa})$. It should be noted that at $400^{\circ} \mathrm{C}$ the greatest strengthening is attained already at $30 \mathrm{~mm} / \mathrm{s}(340 \pm 15 \mathrm{MPa})$ (Fig. 2 b).

The Deform 3D software package used for mathematical modeling of the ECAP process allows one to analyze the thermal fields of the workpiece. However, this complex does not directly take into account the transformation energy of the structure. To solve this issue and improve the quality of the results, we proposed and used an approach that takes into account the energy required to transform the structure through the heat capacity coefficient.

The heat capacity coefficient used in the Deform 3D software package requires correction for the amount of energy spent on the transformation of the structure. Assuming that the total energy expended in the process of deformation $(E)$ is spent on the transformation of the structure $\left(E_{\text {str }}\right)$, heat release (to the environment) $\left(E_{\text {dis }}\right)$ in the process of deformation and overcoming friction forces $\left(E_{\mathrm{fr}}\right)$, we write the following expression:

$$
E=E_{\text {str }}+E_{\text {dis }}+E_{\text {fr }} \text {. }
$$

Our experiments showed that the forces of friction between the bronze workpiece and the steel tooling under lubrication conditions did not significantly affect the thermal fields of the workpiece; therefore, we neglected them in our approach.

The total energy spent on the sample upset can be calculated by the formula [17]:

$$
E=V_{0} \int_{0.2}^{1.1} \sigma d \varepsilon,
$$

where $V_{0}$ is the initial volume of the sample, $\sigma$ is the sample deformation, $\varepsilon$ is the degree of deformation.

Energy converted to heat was calculated as:

$$
E_{\text {dis }}=c \rho V_{0} \Delta T \text {, }
$$

where $c, \rho$ are the material's heat capacity and density, $\Delta T$ is the variation of temperature.

Based on Eq. (1-3), the fraction of dissipated energy (Fig. 1c) and the energy spent on the transformation of the structure was calculated.

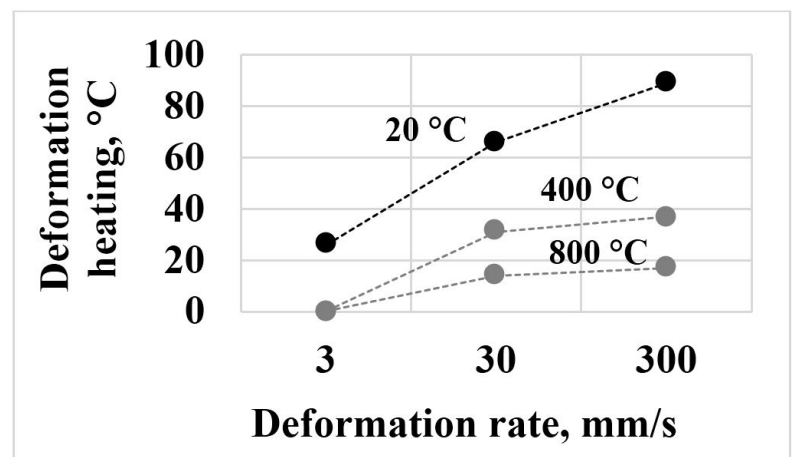

a

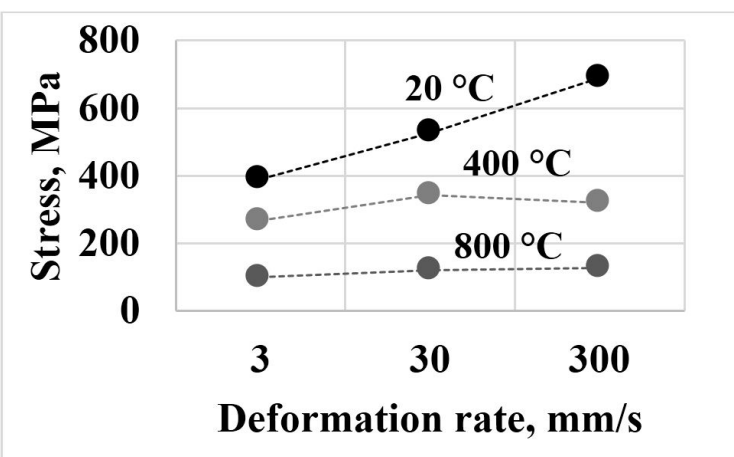

b

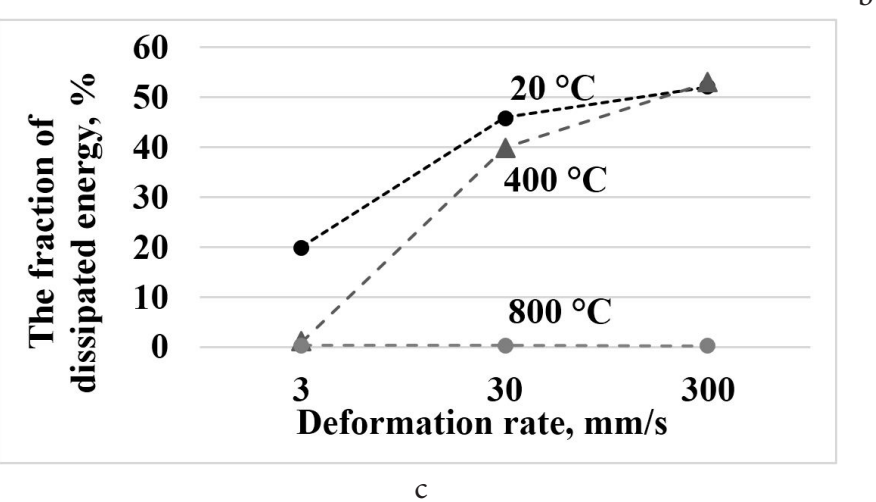

Fig. 1. The heating value for the $\mathrm{Cu}-0.6 \mathrm{Cr}$ alloy in the process of upsetting (a); the stresses in the process of deformation (b); the fraction of dissipated energy in the process of upsetting (c). 
As it can be seen from Fig. 1c, the largest fraction of dissipated energy is observed at a deformation temperature of $20^{\circ} \mathrm{C}$, as well as at a sample deformation rate of $300 \mathrm{~mm} / \mathrm{s}$ and an initial temperature of $400^{\circ} \mathrm{C}$. Due to the material's low yield strength at a temperature of $400^{\circ} \mathrm{C}$, the value of dissipated energy at a rate of $3 \mathrm{~mm} / \mathrm{s}$ is negligibly small.

The heat capacity coefficient used in mathematical modeling was corrected taking into account the measured temperature in a physical experiment during upsetting (the amount of deformation heating in thermocouples) on the Gleeble 3500 physical modeling complex and showed good convergence.

Further, using the corrected heat capacity coefficient obtained as a result of the experiments and theoretical assessment, and the results of upsetting, a database was created and mathematical modeling of the ECAP process of the Cu-0.6Cr alloy in Deform 3D was carried out. As demonstrated by the modeling results, during ECAP processing at a rate of $30 \mathrm{~mm} / \mathrm{s}$ a considerable heating takes place. The maximum increment in temperature, $99^{\circ} \mathrm{C}$, occurs at an initial temperature of $20^{\circ} \mathrm{C}$, whereas at $400^{\circ} \mathrm{C}$ the heating value reaches $63^{\circ} \mathrm{C}$. Thus, the resultant sample temperature in the strain site at $400^{\circ} \mathrm{C}$ lies in the area of the effective aging temperatures $\left(460-470^{\circ} \mathrm{C}\right)$ of the $\mathrm{Cu}-0.6 \mathrm{Cr}$ alloy [18].

As part of the study of the thermal fields of the workpiece during processing by the ECAP method, it was determined how significantly the heat transfer between the sample and the matrix affects the final heating of the sample. Modeling was performed at a deformation rate of $30 \mathrm{~mm} / \mathrm{s}$ and initial temperatures of 20 and $400^{\circ} \mathrm{C}$, taking into account the heat transfer (Fig. 2a,c) and without it (Fig. 2b,d). It has been established that the difference between the temperatures of heating in the strain site does not exceed $8 \%$. The changes involve only the area of the thermal fields from the sample's heating. It has been found that during the deformation at room temperature the deformation force amounts to $218 \mathrm{kN}$ and produces stresses in the die-set exceeding the permissible values (for the die-set material used in the actual conditions, i. e. die steel with an enhanced heat resistance), whereas at $400^{\circ} \mathrm{C}$ the die-set will not experience critical stresses $(F=142 \mathrm{kN})$.

\section{Conclusions}

1. An approach has been proposed and tested to take into account the influence of structural changes in mathematical modeling on the thermal effect of deformation under conditions of high-speed ECAP processing. The approach is based on a physical experiment on samples upsetting on a Gleeble 3500 at different speeds and initial temperatures. On the basis of the proposed approach, the values of the coefficient of "heat capacity" are corrected, which change relative to the known constants due to the expenditure of energy for structural transformation during deformation. It was found that during cold deformation $\left(20^{\circ} \mathrm{C}\right)$, there is a maximum difference (up to $15 \%$ ) between the experimental and table values.

2. By the method of mathematical modeling it is shown that in the process of ECAP of the $\mathrm{Cu}-0.6 \mathrm{Cr}$ alloy at a temperature of $20^{\circ} \mathrm{C}$ and a deformation rate of $30 \mathrm{~mm} / \mathrm{s}$ of the material, it occurs up to $120^{\circ} \mathrm{C}$, and when using tabular values up to $135^{\circ} \mathrm{C}$.

Acknowledgements. The study was carried out by a grant from the Russian Science Foundation (project № 19-19-00432).
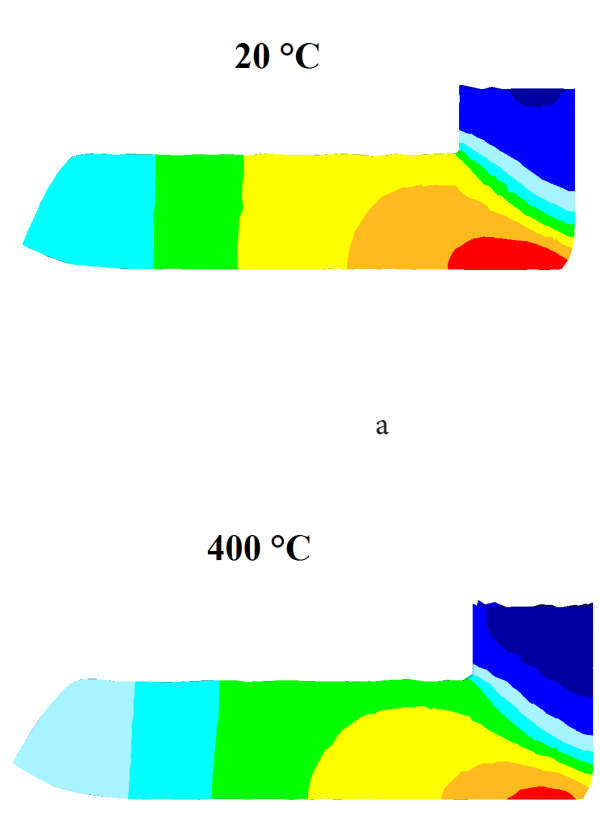
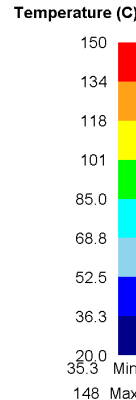

Temperature (C)

$$
\begin{aligned}
& 475 \\
& 466 \\
& 456 \\
& 447 \\
& 438 \\
& 428 \\
& 419 \\
& 409 \\
& 4000 \\
& 4068 \text { Min } \\
& 468 \text { Max }
\end{aligned}
$$

$20{ }^{\circ} \mathrm{C}$

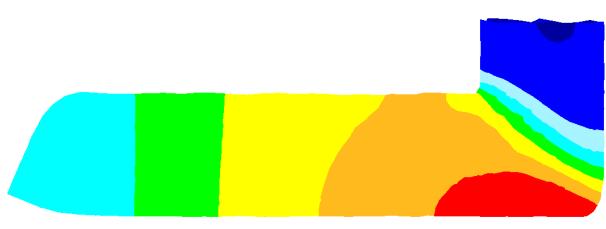

$400{ }^{\circ} \mathrm{C}$

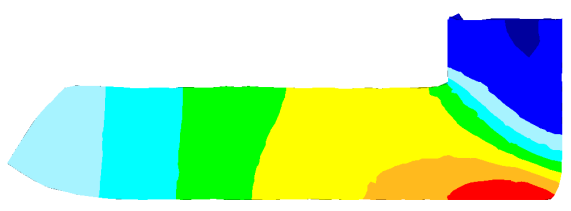

Temperature (C)
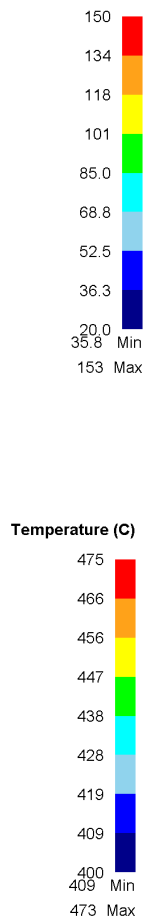

d

Fig. 2. (Color online) Temperature distribution fields in the process of 1 ECAP cycle with heat transfer $(a, c)$ and without heat transfer $(b, d)$ with the matrix. 


\section{References}

1. R.Z. Valiev, R.K. Islamgaliev, I.V. Alexandrov. Prog. Mater. Sci. 45, 103 (2000). Crossref

2. R.Z. Valiev, A.P. Zhilyaev, T.G. Langdon. Bulk Nanostructured Materials: Fundamentals and Applications. John Wiley \& Sons, USA (2014) 456 p. Crossref

3. V.A. Shabashov, V.V. Sagaradze, A.V. Litvinov. Mat. Sci. Eng. A. 528, 6393 (2011). $\underline{\text { Crossref }}$

4. V.A. Shabashov, V.V. Sagaradze, A.E. Zamatovskii, V.P. Pilyugin, K. A. Kozlov, A. V. Litvinov, N. V. Kataeva. The Physics of Metals and Metallography. 117 (8), 805 (2016). Crossref

5. I. A. Faizov, R. R. Mulyukov, D. A. Aksenov, S. N. Faizova, N. V. Zemlyakova, K. R. Cardoso, Yu. Zeng. Lett. Mater. 8 (1), 110 (2018). (in Russian) [И. А. Фаизов, Р. Р. Мулюков, Д.А. Аксенов, С.Н. Фаизова, Н.В. Землякова, K. Cardoso, Y. Zeng. Письма о материалах. 8 (1), 110 (2018).] Crossref

6. G. Purcek, H. Yanar, M. Demirtas, Y. Alemdag, D. V. Shangina, S. V. Dobatkin. Mater. Sci. Eng. A. 649 , 114 (2016). Crossref

7. G. Purcek, H. Yanar, D. V. Shangina, M. Demirtas, N. R. Bochvar, S. V. Dobatkin. J. Alloys Compd. 742, 325 (2018). Crossref

8. J. Skiba, A. Dominiak, T.S. Wiśniewski, W. Pachla, M. Kulczyk1, S. Przybysz. Key Eng. Mater. 641, 278 (2015). $\underline{\text { Crossref }}$
9. B.A. Krivitsky. Forging and stamping production. Material processing by pressure. 6, 36 (2011). (in Russian) [Б. А. Кривицкий. Кузнечно-штамповочное производство. Обработка материалов давлением. 6, 36, 2011.]

10. G. J. Raab, R. Z. Valiev, T. C. Lowe, Yu. T. Zhu. Mater. Sci. Eng. A. 382, 30 (2004). Crossref

11. I. G. Brodova, A.N. Petrova. Scientific and technical statements of SPbSPU. Physics and mathematics. 4-1 (182), 213 (2013). (in Russian) [И.Г. Бродова, А.Н. Петрова. Научно-технические ведомости СПбГПУ. Физико-математические науки. 4-1 (182), 213 (2013).]

12. Y.H. Kim, R.H. Wagoner. Int. J. Mech. Sei. 29 (3), 179 (1987). Crossref

13. J.Sh. Karamia. Mater. Res. 19 (3), 640 (2016). Crossref

14. H. S. Kim. Mater. Trans. 42 (3), 536 (2001). Crossref

15. Q.X. Pei, B. H. Hu, C. Lu, Y.Y. Wang. Scripta Mater. 49, 303 (2003). Crossref

16. A. P. Zhilyaev. Letters on Materials. 9 (1), 142 (2019). (in Russian) [А.П. Жиляев. Письма о материалах. 9 (1), 142 (2019).] Crossref

17. J. G. Croeni, J.S. Howe, H. Katō. High Energy-rate Forging and Extrusion and the Effect on Structure and Properties. U.S. Department of the Interior, Bureau of Mines, USA (1966) $31 \mathrm{p}$.

18. D. A. Aksenov, R. Asfandiyarov, G.I. Raab, G.B. Isyandavletova. IOP Conf. Ser: Mater. Sci. Eng. 179, 012001 (2017). Crossref 